А. Є. Іншаков

\title{
КОЛЬОРАТИВ СИНІЙ У СТАРОУКРАЇНСЬКІЙ МОВІ
} (XI-XIII CT.)

Іншаков А. Є. Кольоратив синій у староукраїнській мові (XI-XIII ст.).

Дослідження історії словникового складу української мови неможливе без з'ясування становлення окремих семантичних груп лексики, зокрема кольоративів. У статті розглядається функціонування кольоративу синій та його похідних у староукраїнській мові (XI-XIII ст.). Засвідчено необмежену сполучуваність номена синій, розглянуто використання лексеми в прямому та переносному значеннях.

Ключові слова: кольороназва, лексеми синій, голубий, сизий, кольоратив, похідні слова, абстрактні лексеми. 
Иншаков А. Е. Колоратив синий в староукраинском языке (XI-XIII ст.).

Исследование истории словарного состава украинского языка невозможно без выяснения становлення отдельных семантических групп лексики, в частности колоративов. В статье рассматривается функционирование колоратива синий и его производных в староукраинском языке (XI - XIII ст.). Зафиксирована неограниченная сочетаемость номена синий, рассмотрено использование лексемы в прямом и переносном значениях.

Ключевые слова: цветонаименование, лексемы синий, голубой, сизый, колоратив, производные слова, абстрактные лексемы.

Inshakov A. Y. The colorative dark blue in the Old Ukrainian language of the 11th -13 th centuries.

An investigation of the history of the Ukrainian vocabulary is hardly possible without definition of a formation of separate semantic vocabulary groups, the coloratives in particular. The article deals with the functioning of the colorative dark blue, widely used in ancient texts, and its derivatives in the Old Ukrainian language of the 11 th -13 th centuries. The author states unlimited combinations of a nomen dark blue and examines the use of the lexeme both in the literal and metaphorical sense of the word.

Key words: the name of colour, lexeme dark blue colorative, light blue, dove-coloured, derivative words, abstract lexemes.

Питання історії становлення окремих тематичних груп лексики на різних етапах розвитку мови постійно привертають увагу мовознавців. Проте багато 3 тематичних груп лексики в аспекті діахронії не досліджено. Останні $30-50$ років у мовознавстві значно посилився інтерес лінгвістів до кольоронайменувань.

У східнослов'янській мовознавчій літературі досі значна увага приділялася проблемі функціонування кольоронайменувань (М. Чікало, О. Рудь, В. Кушнерик, Л. Довбня, І. Бабій, А. Критенко, М. Іщук; Н. Бахіліна, В. Москович, Н. Пелевіна, В. Юрик, І. Кулікова, М. Суровцева, Н. Степанова, Л. Грановська, А. Панченко та ін.).

Дослідження кольороназв староукраїнського періоду є важливим для процесу становлення, функціонування відповідної тематичної групи, виявлення закономірностей формування історичної лексикології української мови загалом. Різноманітним із семантичного боку, активним шаром словникового складу української мови $\epsilon$ кольоративи. В україністиці досі не здійснювався на широкому історичному матеріалі комплексний діахронічний розгляд кольоративів. Цим i зумовлено актуальність нашого дослідження. Однією 3 частотних мікрогруп $\epsilon$ лексеми на позначення синього кольору.

Метою нашої статті $є$ виявлення лексико-семантичного поля кольору синій та його похідних, аналіз функціонування найбільш уживаного кольоративу в давніх текстах староукраїнської мови (XI-XIII ст.).

Староукраїнська спадщина в лексиці сучасної української мови на позначення кольорів незначна. Така обмеженість основних кольороназв пояснюється специфікою жанрів, своєрідністю поетики давньої літератури. В обстежених нами джерелах виявлено близько двох десятків кольоронайменувань. Переважно це основні кольори та їх відтінки, і лише зрідка фіксуємо назви змішаних кольорів. Часто вживаною кольороназвою в джерелах періоду Київської Русі є лексема синій.

Прикметник синій у давнину мав складну систему значень, зумовлену його історією. 
Синій (д.-p. синь, исл. синь) споріднений із сяяти чи сивий, лит. šyvas «світлої масті», д.-інд. cyātas «чорний, темний». Співзвучні фіноугорським назвам: piн. sini «синій колір», морд. sen «синій» та ін. (Ф III 624). Пов'язана 3 назвою синій лексема синиця, д.-p. синица (там само 625). Утворена від кольору синій табуїстична назва синець «чорт» (там само 624).

Синій - колір, середній між голубим і фіолетовим, утворений від короткої форми синь із додаванням закінчення -и. Лексема походить від

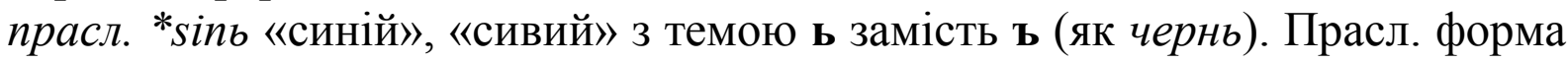
*sinb утворена від кореня *si-/*sei- 3 суфіксом -n-ь-, подібно до дієслова сяяти «блискучий, сяючий». Цей же корінь є і в прикметниках $\underline{c t d b u}$, c Łpblu (сивий, сизий). У давнину не було чіткого розмежування кольорів. Наприклад: д.-р. прикметник синии «синій, темно-голубий, багровий, чорний», схв. сиิғи «сіруватий, синій», д.-інд. с̧уатmas «чорний, темний», лит. syvas «білий», šẽmas «сіруватий». Через субстантивацію прикметника синь «синій» виник іменник синь «синій колір, синява». Від цього прикметника з суфіксом -ев- утворений іменник синева спершу «синяк» (конкретне), далі - «синій колір» > «синій простір», з суфіксом -як-ъ іменник синякъ > синяк «посинілий синяк на тілі», з суфіксом -t-ти дієслово син $\mathbf{6} т и$ > синіти «ставати синім, виділятися синім кольором» (в українській мові 3 i), 3 суфіксом -и-ти - дієслово синити > синити «фарбувати в синій колір», від цього дієслова з суфіксом -ьк-а утворений іменник синька «дія синити» і «фарба для підсинювання» (білизни, паперу i т. ін.). Похідне слово синиия - «співоча пташка загону горобиних», загальнослов'янське, утворене $з$ праслов'янського * sinica «синиця». $€$ різні гіпотези тлумачення походження цього слова: 1) від *sinь «синій, сизий» 3 суфіксом -іс-а > иц'-а (назва птаха за кольором пір'я); 2) назва утворена від звуконаслідування (ЦЭСРЯ 377).

У давніх пам'ятках виявлені такі значення прикметника синии:

1) «темно-голубий, синій»: въ доць своиства сжть чрьвенон и сине и зелено и багърано (1073 Ізб. 247); явишася столпове черлени, зелени, синии оба польг солнща (1230 Сp III 356); се бо Готскія красныл д ъвы въсп тиа на брез синему морю (XII СПІ 25);

2) «синюватий, що відливає голубим кольором (як епітет блискавки)»: чръныя тучя съ моря идутъ, хотять прикрыти б́ солнияа, а въ нихъ трепещуть синіи мльніи (там само 12);

3) «посинілий від синців» оже придеть кръвавъ можже на дворь или синь, то видока ємоүне искати (1019 ПР 83); кто биєть дроуга д тревъмь, а боуд $\mathbf{k m е ~ с и н ь , ~ л ю б о ~ к р о в а в ъ , ~ п о л о ц т о р ы ~ г р и в н ы ~ с е р е б р а ~ п л а т и т и ~ ю и о г ~}$ (1229 Cp III 356);

4) «багровий, налитий кровью»: комог сини очи, не пр tббывањщиимъ ли въ вин ъ, не назирањщиимъ ли, къде пирове бывњвть (XI Cp III 356); 
5) «темний, темно-синій»: скочи оть нихъ лютыль зв тремъ въ

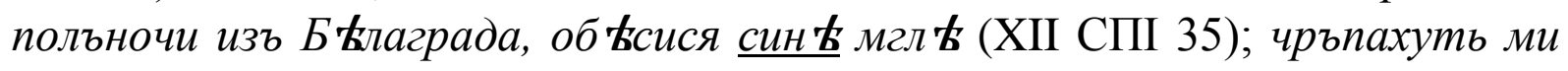
синие вино, съ трудомь см тиено (XII СПІ 23) - епітет вина;

6) «темношкірий» фіксується пізніше, з XV ст.;

7) «чорний»: синя гако сажа (Ж. Андр. Юр. 156). Про диявола: глаголаше синіи: ...мою волю д ъеть, немилостивъ бо и сребролюбець съ Богомь части не им ъеть (Ж. Андр. Юр. 107); рече синіи..., отв тщав же св ътльи ангель (там само 108);

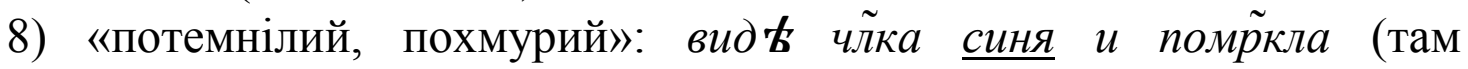
caмo 187).

Пізніше з XV ст. у російських джерелах трапляються Синґа орда «Ногайська орда»; Синее море «Аральське море».

У джерелах зафіксовані похідні суфіксальні іменники від прикметника синии. Наприклад: синева «синець»; синета, синота «пряжа і тканина синього кольору, вісон»: не бо Бг̃ почиваєть на синет қ и на багърт (1073 Ізб. 121); синица «синиця»: коли пожреть синица орла...,тогда безумныли уму научится (Сл. Дан. Зат.), пізніше зафіксовано синь «синій колір; синє поле, головний колір у тканині»; синьцьь 1) «чорний» (про диявола): вопрошати нача ангель Господа о тяжи тои; синець же абіе отвратися на запад (Ж. Андр. Юр. 108); син'ии m tин ' служаху, по немь ходяще (там само 192); 2) «як назва народу - ефіоп»: m tиъ бо образомь ся гавиль, гако же старыи Синець (там само 10); дієслівні деривати син kmи, син қю: син қюша власы своими (XI/XVI ИФ I 247); безафіксне похідне синь «синець»: или боудеть кровавъ или синь надъраженъ, то не искати ем оу видока челов ъкоу томоу... (XI ПР 76); складний дериват и при 'хxа въ Синеволодьско (иневодско). во манастьрь сїь а Бйa (1240 ЛІ 787).

Як бачимо, цей прикметник використовувався для назви кольору водних джерел (моря, річки), опису природних явищ, характеристики людської зовнішності, тканини, предметів, кольору шкіри, диявола: на синемъ море, синее небо, синего Дону, синии молнии (СПІ), муж синь (ПР), сини очи, син мәлt, жел вино, люди сини, еөіопь сини, синяґ лица. У «Слові...» широко використовуються народно-поетичні визначення-характеристики, постійні

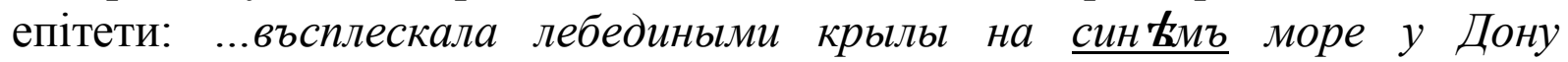
плешучи... (XII СПІ 19); ...и не сошлю къ синему морю (там само 24).

Фактичний матеріал свідчить, що, мабуть, у давнину номен синій не виступав остаточно як один з основних кольорів спектру. Імовірно, слово було багатозначним, означало просто темний колір (значення 5-8). Не зовсім зрозумілі значення кольору в сполуках синее вино, сини очи, син tюша власы, можливі тут переносні значення.

Відтінок синього кольору - голубий з'являється в пам’ятках пізніше. 
Українське голубий походить, мабуть, від голуб (cm.-сл. голжбь) - за синім вилиском шийного пір'я голуба. Спершу похідне від назви кольору, але через обмежене поширення у слов'ян стосовно відносно до *golqbb (Ф I 432).

Голубий - «колір ясного неба», «лазурний», «блакитний, (про масть) темно-сірий». Східнослов'янське слово за пам'ятками відоме з XIII ст.

Праслов'янська форма розвинулася $3 *$ golqbb через зміну $\mathbf{Q}(\boldsymbol{x})>\mathbf{y}$. Давнє *golgbb утворене 3 предметним суфіксом *-Qb-ь>-уб-ь від кореня *ghel-/*ghol- > гол - зі значенням кольору «жовтий». Чергування голосних е(ь)//о пов'язано 3 прикметником жьлть > жёлтый > жовтий (ЦЭСРЯ 87). На таку аморфність, свободу тлумачення звертає увагу Н. Ф. Пелевіна, досліджуючи функціонування номенів сивий, голубий стосовно червоного кольору: «Слов'янські означення синього і голубого кольорів виникають пізно, і в них можна простежити інші кольорові значення, найчастіше ахроматичні («білий», «сірий», «чорний»). Так, російське голубой, пов’язане з голуб, первісно означало «сірий».

Трапляється номен голубий у пам'ятках зрідка, за СДЯ - три випадки вжитку голУбыи: явишася оба поль его (солнща) столпь черлены, и желты, зелены, черны, голубы, сини (1230 Cp I 546), на позначення масті коней: къне голубыл, кобылка голуба (XIII/XIV СДЯ II 350).

Часто вживаним у пам'ятках був іменник голољбь (51 фіксація за СДЯ): голуби же и воробьеве полет қиа въ гн ъзда свог (946 ЛЛ 17); кротъкыл гако голоуби (XI Cр I 546). Похідні деривати:

- голУбьникъ «голуб'ятня»: голуби же и воробьеве полет ъиа въ гн ъзда свог, шви въ голубники. врабь вве же подь стр қхи. и тако възгараху сл голубьнищи (946 Cp I 546);

- гол 8бичь «пташеня голуба», «голуб»;

- гол 8бичищзь «пташеня голуба», «голуб»;

- гол 8бица «голубка»;

- гол 8бинъ - прикметник від гол 8бъ «голубиний» (Сp I 545);

- голоббиныи (20 прикладів за СДЯ) «що належить голубу»: въ

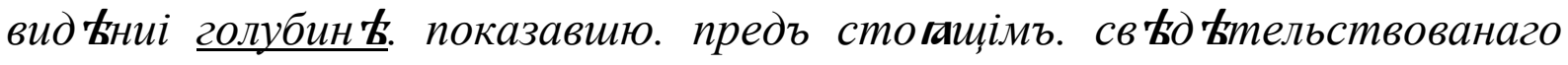
(1284 СДЯ II 350).

В «Іпатіївському літописі» прикметник голубий виступає у складі топоніма - Гол8был л $\mathbf{6 c b}$ «назва місцевості в Київській області»: пов ъдаша в ъжи и стада Полов қикая у Голубого л қса (1187 ЛІ 227). Можливо, сюди ж слід віднести Голубьнъ камень (ИФ 391) - «назва скелі поблизу Ієрусалима».

До складу цієї групи належить змішаний колір, в основі якого синій, - сизий. Українське сизиц̆, д.-p. иизыли походить від того ж кореня, що й сивий. Поодинокий приклад фіксуємо в «Слові о полку Ігоревім»: uизыль орломь подь облакь (XII СПІ 3) (сизий орел - постійний епітет). 
Відбувається змішування букв, що позначають шиплячі та свистячі: замість (c) уживається (ші) - иззым орлом (сизымм). Ця плутанина типова для псковської говірки, на території якої, на думку мовознавців, було переписано втрачений рукопис «Слова...». Часто вживаний колір пір'я птахів виступає постійним епітетом і у фольклорі: сизий голубочок, орел сизий та ін.

Мабуть, до цієї групи можна віднести давній прикметник зекр(bй) або изекрыи «блакитноокий», тільки церковнослов'янське з коливанням форми; зекръ,$\underline{\text { иекръ }, ~ з е р к ъ . ~ Е т и м о л о г и ~ п о я с н ю ю т ь ~ ф о р м о ю ~ з р і т и, ~ в и х і д н а ~}$ форма затемнена (Ф II 95).

У пам'ятках номен трапляється зрідка: прикметник $\underline{3 \text { ťkр }}$ «голубуватий»: нарицаємыи варимюнъ. образъ же юео з ткръ. III 435). Варіанти зекрыл = зеркыли, з ткрыи, изекрыи, из ткрыли позначали «синьоокий, блакитноокий», «голубий», «бірюзовий»: вир жулишнъ из tккръ оубо жсть (1073 Ізб. 154), ґсть н ткто из ткръ и смагль (там само 230).

Як правило, цей прикметник та його варіанти передавали колір очей або колір каменя. При перекладі з грецької - слово багатозначне: світлосиній, голубий, світло-сірий, сизий, зеленуватий, світлий, виблискуючий. Якщо етимологія пояснюється словом зріти, то це, на нашу думку, може бути просто «світлоокий» щодо очей або позначати блиск стосовно каменя. Наприклад: прьвыинадесят вирилионъ. и з қкрь убо есть обр тпаетьжеся и ть въ тои же гор $\mathbf{6}$ (XII Истрин 154); бъ же отроковица чиста, плъна, круговатымъ лицемъ, и з бкра, и възрасла (Хрон. И. Малалы 7); Нестерь великъ т қломъ и очима и носомъ и зеркъ дльголикъ (там само 10). Слово в пізніших пам'ятках не зафіксовано.

Трапляється в пам'ятках i номен, що означає «яскраво-синій, блакитний» - лаз фрь «лазурний колір, лазурне поле тканини»: в украшенъ зв қздами златыми на лазорт (1259 ІЛ 843). Порівняймо: в ч. lazur «блакить; синя фарба», сль. lazur «блакитна фарба», болг. лазур «блакить», через посередництво польської, середньоверхньонімецької, середньолатинської мов запозичено 3 арабської; для д.-p. лазорь припускається посередництво середньогрецької мови (ЕСУМ III 184); (Ф II 450).

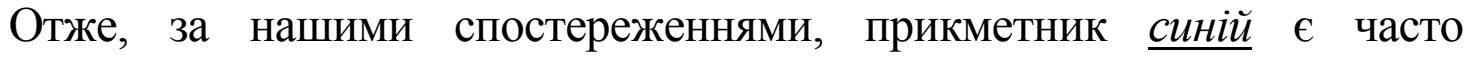
вживаним у староукраїнських пам'ятках. Лексема має необмежену сполучуваність, використовується в прямому та переносному значеннях, виступає у складі численних мікрогруп. У писемних джерелах функціонує чимало похідних абстрактних іменників, дієслів. Цей прикметник використовувався для назви кольору водних джерел (моря, річки), опису природних явищ, характеристики людської зовнішності, тканини, предметів, кольору шкіри та ін. Лексико-семантичне поле синього кольору в давніх пам'ятках представлене лексемами синій, голубий, сизий, зекрыи, лаз рьь. 
EСУM

Ж. Андр. Юрод. 1073 Ізб.

Истрин

ИФ

ЛI

ЛЛ

ПР

СДЯ

Сл. Дан. Зат.

CIII

$\mathrm{Cp}$

$\Phi$

Хрон. И. Малалы ЦЭСРЯ
Перелік умовних скорочень використаних джерел

Етимологічний словник української мови / За ред. О. С. Мельничука : у 7-и т. Т. 1-5. - К. : Наук. думка, 1982-2006.

Житие Андрея Юродивого ХІІв., сп. XVI в. // цит. за Бахіліною.

Изборник великого князя Святослава Ярославича 1073 года. - Спб., 1880. $266 \mathrm{c}$.

Истрин В.М. Александрия русских хрононографов. - М., 1894. - Кн. 1-2.

Мещерский Н. А. История иудейской войны Иосифа Флавия в древнерусском переводе. - М.-Л. : Изд-во АН СССР, 1958. - 578 с.

Ипатьевская летопись. - [2-е изд.]. - Спб., 1908. - 938 с. - (Полн. собр. рус. летописей; Т. 2).

Лаврентьевская летопись. - [2-е изд.]. - Л. : Изд-во АН СССР, 1926 - 1927. -

580 с. - (Полн. собр. рус. летописей; Т. 1, Вып. 1 -2).

Правда Русская. Т. 1. Тексты подгот. к печ. В. П. Любимов, Н. Д. Лавров, М. Н. Тихомиров, Г. Л. Гейерман и Т. Е. Кочин; Под ред. акад. Б. Д. Грекова. М.-Л. : Изд-во АН СССР, 1940. - 506 с.

Словарь древнерусского языка (XI - XIV вв.) : в 10 т. / Гл. ред. Р. И. Аванесов. М. : Рус. яз., 1988 - 1991. - Т. 1-4.

Слово Даниила Заточника по редакциям XII и XIII в. и их переделкам / Подгот. к печ. Н. Н. Зарубин. - Л. : Изд-во АН СССР, 1932.

Слово о полку Игоревһ // Ироическая песнь о походе на половцев удельного князя Новгорода-Северского Игоря Святославича. - М., 1800. - С.1 - 48.

Срезневский И. И. Материалы для словаря древнерусского языка. - Спб., 1893 1912. - T. $1-3$.

Фасмер М. Этимологический словарь русского языка : В 4 т. / Пер.с нем. и доп. О.Н. Трубачева. - М. : Прогресс, 1964 - 1973. - Т. 1-4.

Истрин В.М.Хроника Иоанна Малалы в славянском переводе, 1911. - Кн. 6 - 9 Цыганенко Г.П. Этимологический словарь русского языка : Более 5000 слов. [2-е изд., перераб. и доп.]. - К. : Рад. шк., 1989. - 511 с. 